\title{
Cytogenetic and Biochemical Changes Induced by Bisphenol A on Testis of Albino Rats and Possible Protection of Black Seed Oil
}

\author{
Original \\ Asmaa H. Atwa', Amal A. Ahmed ${ }^{1}$, Neamat F. Hamed', Amira A. Raouf ${ }^{2}$ \\ Article \\ ${ }^{1}$ Forensic Medicine and Clinical Toxicology Department, Faculty of Medicine (Girls), \\ Al-Azhar University. \\ ${ }^{2}$ Cell Biology Department, National Research Center
}

\begin{abstract}
Background: Bisphenol A (BPA), an estrogenic compound, is one of the world's highest production volume chemicals used in polycarbonate plastics in many consumer products and epoxy resins lining food containers. The BPA is known to have toxic effects on various systems in man and animals.

Objective: To evaluate the cytogenetic and biochemical changes induced by BPA on testis of albino rats and the possible protective effect of black seed oil.

Materials and Methods: This study was carried out on 80 rats, divided into four equal groups (20 rats each). Group I: negative control. Group II: received black seed oil (2ml/ kg BW), Group III: administered BPA (25mg/ kg BW), Group IV: administered BPA + black seed oil of same doses. Blood, testis and epididymis were collected for biochemical and cytogenetic evaluation.

Results: BPA caused a significant decrease in sperm count, total content of DNA, RNA and protein in the testis, with a significant increase of DNA damage of spermatocyte, head and tail abnormalities compared to controls. Co-administration of BPA+ black seed oil resulted in a significant improvement of sperm count, total content of DNA, RNA and protein with significant decrease in DNA damage of spermatocyte and head and tail abnormalities compared to BPA group. Also, BPA group showed a significant decrease in serum testosterone and catalase levels, with a significant increase of super-oxide dismutase (SOD) compared to controls. However, BPA + black seed oil group showed significant improvement of serum testosterone, catalase and SOD levels compared to BPA group.

Conclusion: Exposure of rats to BPA resulted in reproductive toxicity through inducing significant DNA damage and impaired synthesis of DNA, RNA and protein in testicular tissue. Black seed oil attenuate oxidative damage in rat testis via upregulating the activities of enzymatic antioxidants catalase and SOD.
\end{abstract}

Key Words: Comet assay, bisphenol A, black seed oil, rat, testis.

Received: 17 September 2019, Accepted: 05 October 2019

Corresponding Author: Amal Abdel Megeed Ahmed, Forensic Medicine and Clinical Toxicology Department, Faculty of Medicine for Girls, Al-Azhar University, Cairo, Egypt, Tel.: +20 1284567948, E-mail: amal.mohamed53@yahoo.com

ISSN: 2090-7265, Journal of Recent Advances in Medicine Vol 1 issue 1 January 2020

\section{INTRODUCTION}

Bisphenol A (BPA) is one of the world's highest production volume chemicals used in polycarbonate plastics in many consumer products, baby bottles, and epoxy resins lining drink and food containers, medical devices and dental sealants ${ }^{[1]}$. BPA is identified as a potential endocrine disruptor based on its estrogenic properties and toxic effects on germinal cells, which lead to disturbance in hormone production ${ }^{[2]}$. The possible genotoxicity of BPA has been tested in a variety of in vitro and in vivo studies, but the results are controversial ${ }^{[3]}$.

Heat, repeated washing of polycarbonate products and contact with either acidic or basic compounds accelerate hydrolysis of the ester bond linking BPA molecules in polycarbonate plastics and resins resulting in an increase in the rate of leaching of BPA. BPA is absorbed from gastrointestinal tract into the blood and redistributed to other tissues ${ }^{[4]}$. The oxidative stress was proposed as another adverse cellular effect of BPA. BPA increased the generation of reactive oxygen species (ROS) and induced cellular apoptosis. It is known that several antioxidants can protect against BPA-induced toxicity ${ }^{[5]}$.

Nigella sativa (black seed) is a widely used medicinal plant all over the world and has been used in the treatment of different diseases. Acute and chronic toxicity studies have confirmed the safety of Nigella sativa oil and its most abundant active component, thymoquinone, particularly when given orally ${ }^{[6,7]}$. 
The aim of the present study was to evaluate the cytogenetic and biochemical changes induced by bisphenol A on the testis of adult male albino rats and the possible protective effect of black seed oil.

\section{MATERIALS AND METHODS}

\section{Materials}

\section{Animals}

The present study was carried out on 80 adult male albino rats, of three months age (180200- gram). The animals were obtained from Helwan animal breeding farm, Cairo, Egypt. The choice of the rats in this study was due to many metabolic similarities between rat and human ${ }^{[8]}$. The animals were housed in clean stainlesssteel cages under the same environmental conditions. They were kept for acclimatization two week prior to the start of the experiment. The handling of animals followed the rules for the experimental research ethics approved by Research Ethics Committee at faculty of Medicine for Girls Al-Azhar University according to Kostomitsopoulos and Durasevic ${ }^{[9]}$.

\section{Chemicals}

a. Bisphenol A (BPA) was supplied by Sigma Company USA as $97 \%$ purity in the form of white powder and suspended in distilled water, $2 \mathrm{ml}$ of this suspension for each rat.

b. Black seed oil was purchased from El-captain Company (CAPPHARMA), the 6 October City, Egypt.

c. The reagents for the measurement of the different parameters were obtained from Bio diagnostic and Sigma Company.

\section{Methods}

\section{Experimental Design}

According to Bian et al. and AboulEzz et al., ${ }^{[10,11]}$ the animals have been divided into 4 groups 20 rates each. All groups have received the BPA by oral gavage daily for six weeks, five times/week.

Group I: Rats served as negative controls and were received distilled water.

Group II: Rats were received black seed oil ( $2 \mathrm{ml} / \mathrm{kg}$ bw).

Group III: Rats were administered BPA at dose of $25 \mathrm{mg} / \mathrm{kg}$ bw.

Group IV: Rats were administered BPA + black seed oil $(25 \mathrm{mg} / \mathrm{kg}+2 \mathrm{ml} / \mathrm{kg} \mathrm{bw})$.

The animals were fasted overnight and lightly anaesthetized with diethyl ether. Blood samples were obtained from the retro orbital sinus puncture into heparinized capillary tubes from each rat before killing. Collected blood was left to clot at $37^{\circ} \mathrm{C}$ incubator till clot retraction had started and serum separated from the clot. The clear supernatant serum was centrifuged at $4000 \mathrm{rpm}$ for 15 minutes, then collected using a pastier pipette and stored at $-20^{\circ} \mathrm{C}$ for biochemical evaluation. All groups have been sacrificed using diethyl ether. Both testis and epididymis have been dissected and prepared to be subjected to the cytogenetic study".

The following parameters were done at Cell Biology Department of National Research Center, Dokki (Cairo).

\section{Cytogenetic evaluation}

\section{a. Sperm count and their morphology}

Evaluation of sperm count, and their morphology was done according to the technique described by Wyrobek et al..$^{[12]}$. For each animal about 1000 sperms were examined for presence of morphological abnormalities (amorphous and banana heads) and (coiled and divided tails).

\section{b. Comet assay}

Endogenous DNA damage measured as the mean comet tail DNA of spermatocytes for the studied groups (20 rats each). The number of cells scored for each animal was 100 cells $^{[13]}$. The comet assay was performed according to the procedure of Singh et al. ${ }^{[14]}$ with modification of Klaude et $a l^{[15]}$ as described by Blasiak et al. ${ }^{[16]}$

\section{c. Total Content of DNA, RNA and Protein}

\section{Extraction of Nucleic Acid}

The nucleic acids were extracted from testes for determination of DNA and RNA concentration ${ }^{[17]}$.

\section{Determination of DNA Concentrations}

Concentration of DNA was determined in the nucleic acid extracted by diphenyl amine method described by Dische and Schwartz ${ }^{[18]}$. Result of tissue DNA concentration $(\mathrm{mg} / \mathrm{gm}$ tissue) was shown by stander DNA.

\section{Determination of $R N A$ Concentrations}

Concentration of RNA was determined in the nucleic acid extracted by Orcinal procedure described by Dische ${ }^{[19]}$. Results of tissue RNA concentration (mg/ gm tissue) was shown in stander RNA.

\section{Determination of Protein Concentrations}

Colorimetric method described by Gornall et al. ${ }^{[20]}$ was used for quantitative estimation of protein.

\section{Biochemical studies}

Serum testosterone level was done according to Rajkowski et $a l^{[21]}$ and measured by Enzyme linked immunosorbent assay. 


\section{Quantitative estimation of serum superoxide dismutase (SOD)}

The method described by Nishikimi et al. ${ }^{[22]}$ was used for quantitative estimation of SOD (E C.1.15.1.1.).

\section{Reagents}

- Reagent (1): A bottle containing phosphate buffer $\mathrm{pH} 8.5$

- Reagent (2): A bottle containing NBT reconstituted in $10 \mathrm{ml}$ distilled water.

- Reagent (3): A bottle containing NADH reconstituted in $10 \mathrm{ml}$ distilled water.

- Reagent(4): Abottle containing phenadinemetho sulphate (PMS) reconstituted in $10 \mathrm{ml}$ distilled water.

\section{Quantitative estimation of serum catalase (CAT)}

The method described by ${ }^{[23]}$ was used for quantitative estimation of CAT (E C.1.11.16-.).

\section{Reagents}

- Reagent (1): Chromogenic buffer: A bottle containing phosphate buffer $(100 \mathrm{mM} / 1$, Ph.7.0)

- Reagent (2): A bottle containing $\mathrm{H}_{2} \mathrm{O}_{2}$ (substrate and standard) $(0.5 \mathrm{mM} / 1)$.

- Reagent (3): A bottle containing CAT inhibition.
- Reagent (4): A bottle containing peroxidase enzyme (>2000U/ D, 4-AAP $(2 \mathrm{mM} / \mathrm{L})$.

\section{Statistical analysis}

Data were analyzed using Statistical Program for Social Science (SPSS) version 18.0. Quantitative data were expressed as mean \pm standard deviation (SD). Qualitative data were expressed as comparative statistical analysis (change of \% between the studied groups $)^{[24]}$. The results of the present study were represented in tables and photos. Independent-samples t-test of significance was used when comparing between two means, the level of significance at $p$-value $\leq 0.05$

\section{RESULTS}

\section{Cytogenetic evaluation}

\section{a. Sperm count}

Rats administered black seed oil alone showed just significant increase in sperm count $4.48 \%$. while, rats administered BPA $(25 \mathrm{mg} / \mathrm{kg})$ alone or BPA + black seed oil caused a significant decrease $P<0.001$ in sperm count $22.36 \%$ and $12.96 \%$ respectively compared to control. In addition, group III and group IV demonstrated a significant decrease in the sperm count $25.84 \%$ and $16.86 \%$ respectively as compared to group II. Furthermore, group IV showed a significant increase of sperm count $10.80 \%$ compared to group III as shown in (Table 1).

Table 1: Percentage of change between the studied groups of the effect of bisphenol A (BPA) on sperm count and serum testosterone level (ng/ ul) of adult male albino rats and the possible protection by black seed oil

\begin{tabular}{lcccccc}
\hline \multirow{2}{*}{ Groups } & \multicolumn{3}{c}{ Sperm count } & \multicolumn{3}{c}{ Serum Testosterone level (ng/ ul) } \\
\cline { 2 - 7 } & \% change & t-test & P-value & \% change & t-test & $P$-value \\
\hline Group (I) vs. Group (II) & 4.48 & 2.828 & $0.047^{*}$ & 5.26 & 2.147 & $0.050^{*}$ \\
Group (I)vs. Group (III) & 22.36 & 9.500 & $0.001^{*}$ & 58.87 & 20.390 & $<0.001^{*}$ \\
Group (I) vs. Group (IV) & 12.96 & 7.778 & $<0.001^{*}$ & 29.71 & 9.642 & $<0.001^{*}$ \\
Group (II) vs. Group (III) & 25.84 & 11.500 & $<0.001^{*}$ & 61.04 & 25.127 & $<0.001^{*}$ \\
Group (II) vs. Group (IV) & 16.86 & 10.607 & $<0.001^{*}$ & 33.41 & 12.683 & $<0.001^{*}$ \\
Group (III) vs. Group (IV) & 10.80 & 4.000 & $0.025^{*}$ & 41.49 & 9.535 & $<0.001^{*}$ \\
\hline
\end{tabular}

*significant $p$-value

\section{Sperm head and tail morphology}

BPA group showed a significant increase in abnormalities of sperm head morphology (amorphous and banana heads) $82.19 \%$ vs 77.99 and sperm tail morphology (coiled and divided tails) 80.00 vs 80.78 respectively compared to group I. While, group IV showed a significant decrease in abnormalities of (amorphous and banana heads) 67.30 vs $69.70 \%$ and (coiled and divided tails) $60.69 \%$ vs $56.54 \%$ respectively compared to BPA group as shown in (Table 2,3) and (Figure 1a-f). 
Table 2: Percentage of change between the studied groups of the effect of bisphenol A (BPA) on sperm head morphology (amorphous \& banana heads) of adult male albino rats and the possible protection by black seed oil

\begin{tabular}{lcccccc}
\hline \multirow{2}{*}{ Groups } & \multicolumn{3}{c}{ Amorphous head } & \multicolumn{3}{c}{ Banana head } \\
\cline { 2 - 6 } & \% change & t-test & P-value & \% change & t-test & $P$-value \\
\hline Group (I) vs. Group (II) & 27.56 & 1.387 & 0.267 & 20.67 & 1.106 & 0.341 \\
Group (I)vs. Group (III) & 82.19 & 16.793 & $<0.001^{*}$ & 77.99 & 14.083 & $<0.001^{*}$ \\
Group (I) vs. Group (IV) & 45.52 & 3.467 & $0.002^{*}$ & 27.36 & 1.843 & 0.092 \\
Group (II) vs. Group (III) & 87.09 & 19.538 & $<0.001^{*}$ & 82.54 & 16.590 & $<0.001^{*}$ \\
Group (II) vs. Group (IV) & 60.53 & 19.538 & $<0.001^{*}$ & 42.37 & 16.590 & $0.011^{*}$ \\
Group (III) vs. Group (IV) & 67.30 & 13.336 & $<0.001^{*}$ & 69.70 & 13.259 & $<0.001^{*}$ \\
\hline
\end{tabular}

*significant $p$-value

Table 3: Percentage of change between the studied groups of the effect of bisphenol A (BPA) on sperm tail morphology (divided\& coiled tails) of adult male albino rats and the possible protection by black seed oil

\begin{tabular}{lcccccc}
\hline \multirow{2}{*}{ Groups } & \multicolumn{3}{c}{ Divided tail } & \multicolumn{3}{c}{ Coiled tail } \\
\cline { 2 - 7 } & \% change & t-test & P-value & \% change & t-test & $P$-value \\
\hline Group (I) vs. Group (II) & 31.51 & 1.797 & 0.249 & 32.00 & 1.991 & 0.119 \\
Group (I)vs. Group (III) & 80.78 & 12.516 & $<0.001^{*}$ & 80.00 & 18.520 & $<0.001^{*}$ \\
Group (I) vs. Group (IV) & 55.76 & 6.549 & $<0.001^{*}$ & 86.40 & 5.064 & $<0.001^{*}$ \\
Group (II) vs. Group (III) & 86.83 & 13.847 & $<0.001^{*}$ & 82.54 & 20.708 & $<0.001^{*}$ \\
Group (II) vs. Group (IV) & 69.70 & 13.847 & $<0.001^{*}$ & 65.41 & 20.708 & $<0.001^{*}$ \\
Group (III) vs. Group (IV) & 56.54 & 8.761 & $<0.001^{*}$ & 60.69 & 13.094 & $<0.001^{*}$ \\
\hline
\end{tabular}

*significant $p$-value

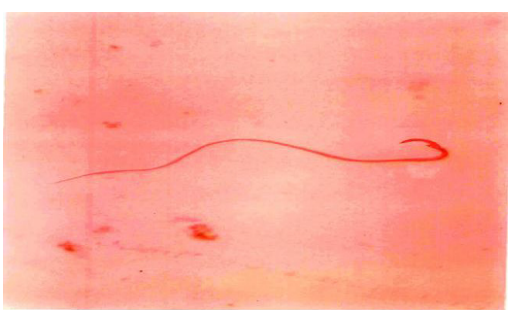

Fig. 1 a: Shows the normal sperm morphology in the control rat (Eosin stain, x 400).

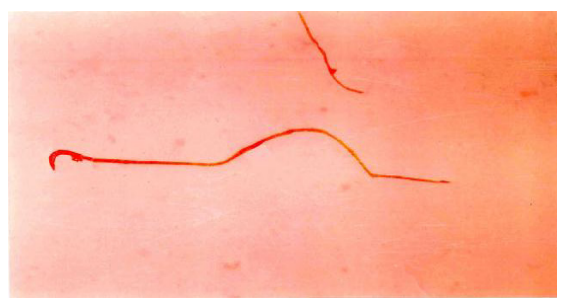

Fig. 1 b: Shows the normal sperm morphology in the control rat (Eosin stain, x 400).

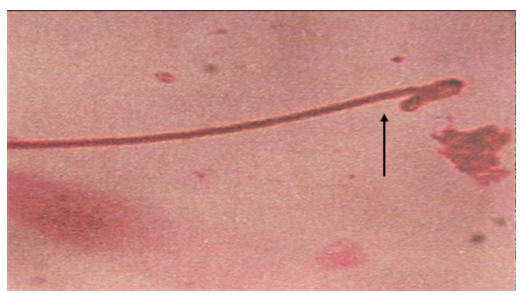

Fig. 1 c: Shows Amorphous head abnormality in rats exposed to bisphenol A (BPA) (Eosin stain, x 400).

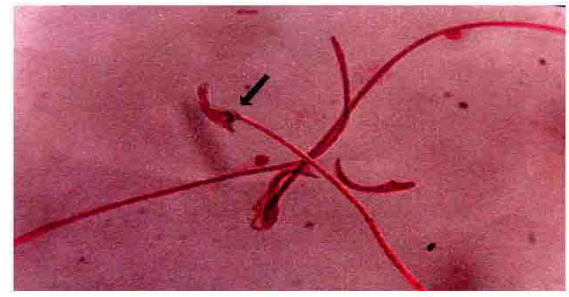

Fig. 1 d: Shows Banana shape head abnormality in rat exposed to bisphenol A (BPA) (Eosin stain, x 400).

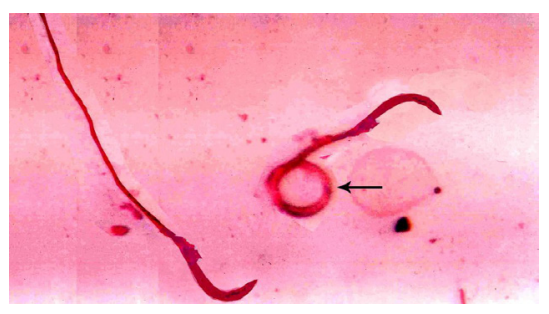

Fig. 1 e: Shows Coiled tail abnormalities in rats exposed to bisphenol A (BPA) (Eosin stain, x 400).

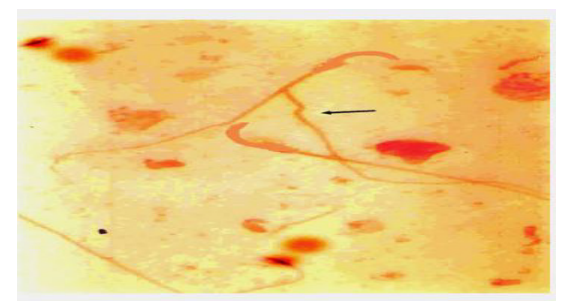

Fig. 1.f: Shows Divided tail abnormalities in rats exposed to bisphenol A (BPA) (Eosin stain, x 400). 


\section{b. Comet assay}

The comet assay revealed that group I and group II showed undamaged spermatocyte, most of DNA located in comet head without tails are shown in (Figure 1g, h) which means no DNA damage is observed.

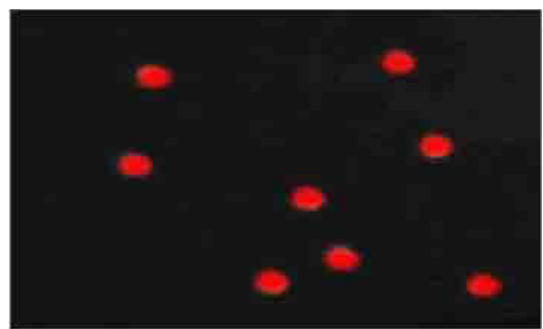

Fig. 1 g: Shows Fluorescent microscope photomicrograph of spermatocyte of group I show no migration out of the nucleus into the tail of the comet.

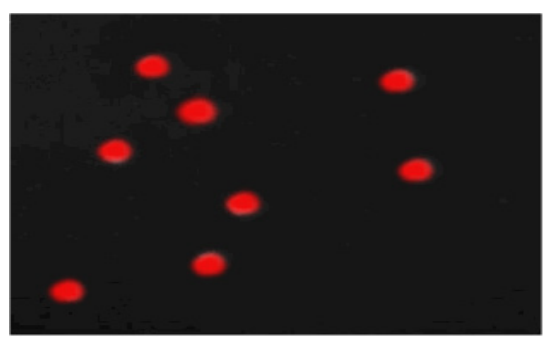

Fig. 1 h: Shows Fluorescent microscope photomicrograph of spermatocyte of group II showing no migration out of the nucleus into the tail of the comet as compared to group I.

BPA caused an increase in DNA strand breaks leading to greater DNA migration out of the nucleus into the tail of the comet in the spermatocyte compared to group I as shown in (Figure 1i). In group IV, there were lesser DNA migration out of the nucleus into the tail of comet as compared to group III as shown in (Figure 1j).

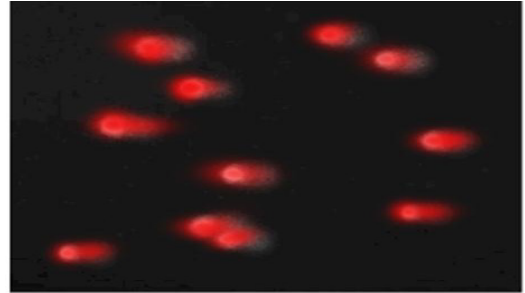

Fig. 1 i: Shows Fluorescent microscope photomicrograph of spermatocyte of group III showing greater DNA migration out of the nucleus into the tail of the comet as compared to group I.

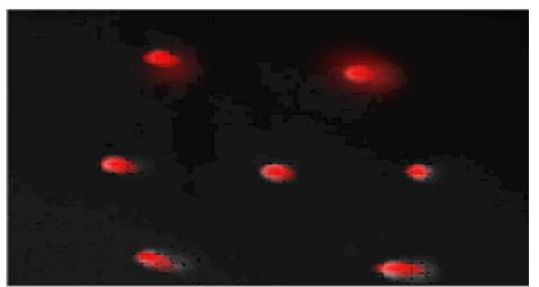

Fig. 1 j: Shows Fluorescent microscope photomicrograph of spermatocyte of group IV (BPA+ Black seed oil) showing lesser DNA migration out of the nucleus into the tail of the comet as compared to group III.

\section{c. Total content of DNA, RNA and protein}

Total content of DNA, RNA and total protein exhibited a significant decrease $42.22 \%, 41.38 \%$ and $37.10 \%$ respectively in BPA group. Whereas, no significant difference was observed in total content of DNA, RNA and total protein of group II and group IV compared to control. Furthermore, there were a significant decrease on total content of DNA, RNA and total protein in group III 49.51\%, 37.04 and 41.23 and group IV $19.42 \%, 5.56 \%$ and $14.77 \%$ respectively compared to group II. Group IV showed a significant increase of total content of DNA, RNA and total protein $37.35 \%, 33.33 \%$ and $31.05 \%$ respectively as compared to the BPA group as shown in (Table 4).

Table 4: Percentage of change between the studied groups of the effect of bisphenol A (BPA) on total content of DNA, RNA (mg/g tissue) and Total protein $(\mathrm{g} / \mathrm{dl})$ in testis of adult male albino rats and the possible protection by black seed oil

\begin{tabular}{|c|c|c|c|c|c|c|c|c|c|}
\hline \multirow[t]{2}{*}{ Groups } & \multicolumn{3}{|c|}{$\begin{array}{c}\text { Total DNA content (mg/ } \\
\mathrm{g} \text { tissue) in testis }\end{array}$} & \multicolumn{3}{|c|}{$\begin{array}{c}\text { Total RNA content (mg/ } \\
\mathrm{g} \text { tissue) in testis }\end{array}$} & \multicolumn{3}{|c|}{$\begin{array}{l}\text { Total protein content (mg/ } \\
\mathrm{g} \text { tissue) in testis }\end{array}$} \\
\hline & $\%$ change & t-test & P-value & $\%$ change & t-test & $P$-value & $\%$ change & t-test & P-value \\
\hline Group (I) vs. Group (II) & 11.65 & 1.45 & 0.160 & 6.90 & 0.720 & 0.479 & 7.03 & 1.819 & 0.119 \\
\hline Group (I)vs. Group (III) & 42.22 & 4.95 & $0.001 *$ & 41.38 & 12.53 & $0.001 *$ & 37.10 & 10.78 & $0.001 *$ \\
\hline Group (I) vs. Group (IV) & 7.78 & 0.93 & 0.362 & 12.07 & 3.736 & $0.004^{*}$ & 8.78 & 2.46 & $0.001 *$ \\
\hline Group (II) vs. Group (III) & 49.51 & 16.4 & $0.001 *$ & 37.04 & 4.250 & $0.001^{*}$ & 41.23 & 15.82 & $0.001 *$ \\
\hline Group (II) vs. Group (IV) & 19.42 & 5.23 & $0.001 *$ & 5.56 & 0.772 & 0.448 & 14.77 & 5.35 & $0.001 *$ \\
\hline Group (III) vs. Group (IV) & 37.35 & 10.6 & $0.001 *$ & 33.33 & 10.01 & $0.001 *$ & 31.05 & 11.84 & $0.001 *$ \\
\hline
\end{tabular}

*significant $p$-value 


\section{Biochemical studies}

\section{Serum testosterone level}

Group II showed just significant increase in testosterone level (5.26\%). While, rats administered BPA alone or BPA + black seed oil caused a significant decrease in testosterone level $58.87 \%$ and $29.71 \%$ respectively compared to control. In addition, group III and group IV demonstrated a significant decrease in testosterone level $61.04 \%$ and $33.41 \%$ respectively compared to group II. Furthermore, group IV demonstrated a significant increase in testosterone level $41.49 \%$ compared to group III as shown in (Table 1 ).

\section{Serum SOD and Catalase}

Group III and group IV demonstrated a significant increase in serum SOD level $69.25 \%$ and $41.60 \%$ respectively compared with control. However, group IV showed a significant decrease in SOD $47.34 \%$ as compared to the BPA group. On the other hand, there was a significant decrease of serum Catalase level in group III \& group IV $49.58 \%$ and $21.65 \%$ respectively as compared to control. Group IV showed a significant increase of Catalase $35.65 \%$ as compared to BPA group as shown in (Table 5).

Table 5: Percentage of change between the studied groups of the effect of bisphenol A (BPA) on serum level of superoxide dismutase (SOD) $\&$ Catalase $(\mathrm{U} / \mathrm{ml})$ of adult male albino rats and the possible protection by black seed oil

\begin{tabular}{lcccccc}
\hline \multirow{2}{*}{ Groups } & \multicolumn{3}{c}{ Serum SOD (U/ml) } & \multicolumn{3}{c}{ Serum Catalase (U/ml) } \\
\cline { 2 - 7 } & \% change & t-test & P-value & \% change & t-test & P-value \\
\hline Group (I) vs. Group (II) & 12.44 & 3.217 & $0.004^{*}$ & 4.50 & 1.872 & 0.075 \\
Group (I)vs. Group (III) & 69.25 & 29.066 & $<0.001^{*}$ & 49.58 & 25.371 & $<0.001^{*}$ \\
Group (I) vs. Group (IV) & 41.60 & 13.364 & $<0.001^{*}$ & 21.65 & 11.298 & $<0.001^{*}$ \\
Group (II) vs. Group (III) & 73.07 & 30.996 & $<0.001^{*}$ & 51.85 & 23.223 & $<0.001^{*}$ \\
Group (II) vs. Group (IV) & 48.87 & 16.054 & $<0.001^{*}$ & 25.17 & 11.430 & $<0.001^{*}$ \\
Group (III) vs. Group (IV) & 47.34 & 18.109 & $<0.001^{*}$ & 35.65 & 16.676 & $<0.001^{*}$ \\
\hline
\end{tabular}

*significant $p$-value

\section{DISCUSSION}

Bisphenol $\mathrm{A}$ is a common endocrine disruptor that can alter the synthesis, metabolism, transport, and elimination processes of endogenous hormones and, thus, of mimicking/antagonizing hormonal activities in the body ${ }^{[25]}$. Nigella sativa (Black seeds) and its derivatives have shown various pharmacological activities including therapeutic efficacy against different human diseases and antioxidant antiinflammatory effects against environmental toxins ${ }^{[26]}$.

Concerning the Sperm count the results of the present study indicated that black seed oil administration caused just significant increase in sperm count in compared to control. These could be explained by $^{[27]}$ as they stated that administration of Nigella sativa caused improvement in semen parameters in albino rat and increased sperm count among infertile men. The increased sperm concentration was due in part to the increase in testosterone and follicular stimulating hormone (FSH) levels in testicular tissue, since these two hormones were responsible for spermatocytogenesis.

In the current study, the oral administration of BPA to rats displayed a significant decrease in sperm count compared to control. This observation was generally in agreement with Karnam et al. ${ }^{[2]}$ who revealed that there was significant reduction in the epididymal sperm count after administration of BPA as compared to control.
The mechanism by which BPA could affect sperm count was explained by Klaunig et $a l^{[28]}$ who concluded that bisphenol A has been shown to accumulate in the fatty tissues and is metabolized by Cytochrome P450. Cytochrome P-450 has been shown to induce ROS that permanently impairs sperm function thereby resulting in decline of sperm counts in men and laboratory animals.

Another explanation was reported by Kadry et al. ${ }^{[29]}$ who revealed that BPA-induced impairment of Sertoli cells had been reported by inhibiting endoplasmic reticulum $\mathrm{Ca} 2+$ homeostasis and the ectoplasmic specialization between Sertoli cells and spermatids. BPA may exert both antiandrogenic and estrogenic effects to impair sperm production $^{[30]}$. Moreover, Thimmappa ${ }^{[31]}$ stated that a dramatic decrease in caudal epididymal sperm numbers was previously considered to be the result of a lower sperm output by the testis and to increase sperm resorption (phagocytosis) in the rat testis and epididymis as a result of increase the number of malformed sperms.

This study revealed that administration of black seed oil and BPA showed a significant increase of sperm count in comparison to administration of BPA alone. This result is in accordance with Tawfeek et al. ${ }^{[32]}$ as they showed a significant increase in the percentage of live/dead sperm of male albino rats in Nigella sativa oil joined to $\mathrm{H}_{2} \mathrm{O}_{2}$ compared with 
$\mathrm{H}_{2} \mathrm{O}_{2}$ group. They concluded that Nigella sativa oil has radical scavenging properties, which may explain the increase in the percentage of live/dead sperms. The anti-oxidative action induced by oil is a result of a direct action or indirect effects, e.g. including antioxidative enzymes cascade.

Regarding the results of abnormalities in sperm head and tail morphology in the present study, there was a significant increase in abnormalities (amorphous and banana heads) and (coiled and divided tails) in rats administered BPA compared to control rats.

These results were in agreement with Karnam et $a l^{\left[{ }^{[2]}\right.}$ as they referred that head and tail abnormality percentages were significantly increased in rats of BPA group as compared to control. They suggested that BPA might have potential mutagenic effects on germ cells that led to abnormal sperm production.

Combination of BPA + black seed oil in the current study caused an improvement in the percentage of abnormalities (amorphous and banana heads) and (coiled and divided tail) as compared to rats administered BPA alone.

These results were in accordance with Tawfeek et al. ${ }^{[32]}$ who demonstrated that the beneficial effect of Nigella sativa oil decrease in the percentage of morphologically abnormal sperms reflects its antioxidants effect that counteracts the $\mathrm{H}_{2} \mathrm{O}_{2}$ effect on sperms.

Also, these results were coincided with Hadi et al. ${ }^{[33]}$ who reported that administration of the plants extracts mixture (Trigonella faenum-graecum seeds, Nigella sativa seeds, and Fraxinus ssp. seeds) to diabetic rats at three periods of study $45,60,75$ days, respectively decreased sperms abnormalities compared with diabetic group.

Concerning DNA damage of spermatocyte evaluated by comet assay, result of this work revealed a significant decrease in DNA damage of spermatocyte in (groupII) as compared to control rats.

This result was in contrast to Al-Shdefat et al. ${ }^{[34]}$ who demonstrated that thymoquinone (TQ) treatment, $(5.0,10$, or $20 \mu)$ increased DNA damage index in a concentration dependent manner compared with control. The geno- protective effect and genotoxic effect of TQ may be related to TQ quinine structure. TQ undergoes one or two electron reductions by cellular reductases. One-electron reduction results in the formation of semiquinones, which are converted to ROS when they react with molecular oxygen. Two-electron reductions produce the antioxidant hydroquinone.

The present study revealed a significant increase in DNA damage in BPA group compared to control.
Result indicated that BPA is a testicular toxic substance and induced a significant DNA damage. This result was coincided with $\mathrm{Wu}$ et al. ${ }^{[35]}$ who stated that BPA administration induced a significant increase in DNA migration within male germ cells. Also, the result of Ulutas et al. ${ }^{[36]}$ reported a significant increase in tail length and tail moment of DNA in rat cells after administration of BPA and concluded that BPA may be genotoxic.

This result could be explained by ${ }^{[37,38]}$ as they indicated that the mechanism of BPA genotoxicity may work through the induction of oxidative stress and the depletion of antioxidant enzymes. Scientific evidence supports the hypothesis that natural estrogens, synthetic estrogen diethylstilbestrol, as well as BPA generate reactive oxygen species (ROS) during biotransformation and that certain reactive species, predominantly quinones, can react with DNA and cause DNA damage. In addition, Sangai et al. ${ }^{[39]}$ stated that BPA produces spermatotoxic effect through induced alteration in testicular DNA and sperm chromatin structure.

The present study revealed a significant decrease in DNA damage of spermatocyte in rats administrated BPA+ black seed oil compared to BPA group. These results could be explained by Kamarzaman et al. ${ }^{[40]}$ who concluded that thymoquinone had significant high antioxidant activity in testicular tissue so protected DNA damage.

The present results of the total content of DNA, RNA and Protein in the spermatocyte of adult albino rats, showed a significant decrease in total content of DNA, RNA and Protein of rats administered (BPA) as compared to control.

These results were coincided with those of El-Beshbishy et al. ${ }^{[41]}$ who reported that rats administered BPA orally, resulted in decreasing total testicular protein content. This might be due to the testicular fluid which contains several stimulatory and inhibitory factors that selectively altered the protein secretion, thus the changes in testicular protein level suggested that there was a reduction in the synthetic activity of testes.

Abdel-Wahab ${ }^{[42]}$ added that bisphenol $\mathrm{A}$ is converted to bisphenol O-quinone that covalently binds to deoxyguanosine to form DNA adducts. The quinone intermediates of bisphenol A might be the ultimate DNA binding metabolites. This binding might prevent RNA polymerase from transcribing the DNA and can inhibit the formation of mRNA. A failure in mRNA formation can result in an inhibition of protein synthesis.

In the present study there was a significant increase of total content of DNA, RNA and Protein in the spermatocyte of rats administrated black seed oil+ 
BPA as compared to BPA group. This result could be explained by Juma and Abdulrahman ${ }^{[43]}$ who revealed that Nigella sativa (Ns) increases thyroxin hormone that in turn increases growth hormone secretion affecting on total proteins synthesis in males, due to increased testosterone as an anabolic agent toward promoting the protein synthesis.

Regarding the serum testosterone level, the present study showed significant increase in testosterone level in rats administrated black seed oil compared to control. This observed result might be found explanation by Marbat et al. ${ }^{[27]}$ as they found significant increase in serum testosterone in infertile men after 3 months administration of $\mathrm{N}$. sativa. The increased testosterone level after N. sativa may be attributed to enhancing FSH and LH release, which leads to improvement in all semen parameters.

Oral exposure of rats to BPA induced a significant reduction in serum testosterone level as compared to control. Cha et al. ${ }^{[44]}$ reported that the testosterone level in the painters decreased significantly, as the BPA exposure level increased. This result could be explained by Nakamura et al. ${ }^{[45]}$ as they demonstrated that BPA and 17 $\beta$-estradiol (E2) dose dependently decreased the expressions of steroidogenic acute regulatory protein (StAR), and steroidogenic enzymes such a P450 side-chain cleavage enzyme s (P450scc) and 17 $\beta$ - hydroxysteroid dehydrogenase (17 $\beta$-HSD-mRNA).

An improvement of the serum testosterone level was observed in the present study in group IV compared to BPA rats. This result explained by AlSeeni et al. ${ }^{[46]}$ who concluded that the protective effect of nigella sativa oil on the testis might be due to its direct cytoprotective effect and/ or indirect antioxidant (potent superoxide anion scavenger) and androgen like activities.

Concerning the results of serum antioxidant enzyme SOD in the present study, BPA caused a significant increase in mean value of SOD of group III as compared to control. This result was in accordance with Kourouma et al. ${ }^{[47]}$ as they stated a significant increase in SOD in BPA rats compared to control. The increased activity of SOD may be due to higher enzyme activity but doesn't mean better anti-oxidative protection of spermatozoa. This increase may be due to its induction by increased production of superoxide (O- 2), which has been implicated in cell dysfunction. In addition, increased superoxide activity has been shown to play an important part in the pathogenesis of different genetic and acquired forms of hypertension in experimental animals.

A significant decreased serum level of SOD after oral administration of BPA+ black seed oil as compared to BPA rats. Danladi et al. ${ }^{[48]}$ who revealed that $\mathrm{N}$. sativa treatment positively protects the alterations in biochemical variables SOD in the Carbon tetrachloride $\mathrm{CCl} 4+\mathrm{N}$. sativa-treated rats.

The present study demonstrated a significant decrease in catalase enzyme of BPA group as compared to control. Such results are matching with previous data, reported by Aboul Ezz et al. ${ }^{[11]}$ who concluded that oral administration of BPA decreased catalase activity.

In the present study there was a significant improvement of serum level of catalase enzyme in rats administered BPA + black seed oil as compared to BPA rats. These data are in harmony with AlMalki and Sayed ${ }^{[49]}$ who stated that rats administered Cisplatin (CP) markedly reduced the catalase activity compared to the control while, administration of Thymoquinone (TQ) increased the activities. Mosbah et al. ${ }^{[50]}$ reported that black seed oil exhibits cerebral, renal, liver and cardiac protective effect against many xenobiotics through its antioxidant action and ability to boost antioxidant enzymes activities in animals.

\section{CONCLUSION}

\section{It could be concluded that}

- Oral administration of BPA to adult male rats elicited reproductive toxicity and inducing a significant decrease in sperm count, serum testosterone level and antioxidant defense system.

- BPA showed an increase in head and tail abnormalities, impaired synthesis of DNA, RNA and protein in testicular tissue and significant DNA damage.

- The genetic DNA damage may be an initiation to multistep carcinogenesis later in life.

- Black seed oil induces favorable effects on reproductive system in BPA rats, and the beneficial effects may be attributable to its anti-oxidative and androgenic effects.

\section{RECOMMENDATIONS}

1. Using plastic products containing BPA should be avoided.

2. It is favorable to use the natural antioxidants (Black seed oil) to avoid the possible toxicity induced by BPA chemical compounds.

3. Further investigations are required to determine the affection of BPA on other systems of the human body.

4. Another study to demonstrate the effect of BPA administration on the pregnant female and offspring rats exposed during gestation and lactation. 


\section{FINANCIAL SUPPORT}

There is no funding for this study.

\section{CONFLICTS OF INTEREST}

There are no conflicts of interest.

\section{REFERENCES}

1. Ritter S. Debating BPA ${ }^{\text {ee }}$ s toxicity. Chem Eng News 2011; 89 (23):5-13.

2. Karnam SS, Ghosh RC, Mondal S and Mondal M. Evaluation of subacute bisphenol-A toxicity on male reproductive system. Veterinary world, 2015, 8.6: 738 .

3. Jalal N, Surendranath AR, Pathak JL, Yu S, and Chung CY. Bisphenol A (BPA) the mighty and the mutagenic. Toxicol Rep. 2018; 5: 76-84.

4. Almeida S, Raposo A, Almeida-Gonz alez M, and Carrascos C. Food Exposure and Impact on Human Health. Comprehensive Reviews in Food Science and Food Safety, 2018, 17.6: 15031517- Institute of Food Technologists ${ }^{\circledR}$

5. Gassman NR. Induction of oxidative stress by bisphenol A and its pleiotropic effects. Environmental and molecular mutagenesis, 2017, 58.2: 6071-.

6. Randhawa MA, Alghamdi MS and Maulik SK. The effect of thymoquinone, an active component of Nigella sativa, on isoproterenol induced myocardial injury. Pak J Pharm Sci, 2013, 26.6: 12159-. https://www.ncbi.nlm.nih. gov > pubmed

7. Tavakkoli A, Ahmadi A, Razavi BM, and Hosseinzadeh H. Black seed (Nigella sativa) and its constituent thymoquinone as an antidote or a protective agent against natural or chemical toxicities. Iranian journal of pharmaceutical research: IJPR, 2017, 16.Suppl: 2.

8. Gad SC and Chengelis CP. The rats: Toxicology, pathology and metabolism. Cited in Animal models in toxicology 1992. New York. Basal. Hong Kong. USA. Chapter 1:21164-.

9. Kostomitsopoulos NG and Durasevic SF. The ethical justification for the use of animals in biomedical research. Archives of Biological Sciences, 2010, 62.3: 781787-.

10. Bayrak O, Kaya A, Bayrak R, Turgut FH, Bavbek N, Kanbay M, and Akcay A. Nigella sativa oil for prevention of chronic cyclosporine nephrotoxicity: an experimental model. American journal of nephrology, 2008, 28.3: 517522-.

11. Aboul Ezz HS, Khadrawy YA and Mourad IM. The effect of bisphenol A on some oxidative stress parameters and acetylcholinesterase activity in the heart of male albino rats. Cytotechnology. 2013; 67(1):14555-.

12. Wyrobek AJ, Watchmaker C- and. Gordon L. Sperm morphology testing in mice. Handbook of mutagenicity test procedures, 1984, 2nd Ed. Elsevier, Amsterdam, 739750-

13. Blasiak J, Arabaski M, Kzupa R, Wozniak M, Kasznicki $M$ and Drzewoski J. DNA damage and repair in type 2 diabetes mellitus. Mutation Research/Fundamental and Molecular Mechanisms of Mutagenesis, 2004, 554.1:2304-297.

14. Singh NP, McCoy T, Tice RR and Schneider EL. A simple technique for of low levels of DNA damage in individual cells, Exp. Cell Res. 1988; 175(1):18491-.

15. Klaude M, Eriksson S, Nygren J and Ahnström G. The comet assay: mechanisms and technical considerations. Mutation Research/ DNA Repair, 1996, 363.2: 8996-.

16. Blasiak J, Gloc E, Wo'zniak K, Drzewoski J, Zadrozny M, Skorski T, et al. Free radical scavengers can differentially modulate the genotoxicity of amsacrine in normal and cancer cells. Mutation Research/Genetic Toxicology and Environmental Mutagenesis, 2003, 535.1: 25- 34.

17. Pears AGE. Histochemistry. Theoretical and applied. Vol. 2: Analytical technology A. G. E. Pearse. Fourth edition. Churchill Livingstone, Edinburgh 1985, fourth Edition. Edinburgh, London Mellowric and New York. p4421055-.

18. Dische and Schwartz. Estimation of nucleic acids. In: Glick D (ed). Methods of Biochemical analysis 1954. Vol. I. New York: Inter science Publishers Inc. p: 299. Quoted from: Fahim FA, Esmat AY, Mady EA, Ibrahim EK. (2003): Antitumor activities of iodoacetate and dimethylsulphoxide against solid Ehrlich carcinoma growth in mice. Biol Res. 2003; 36(2):253- 62.

19. Dische. Determination of pentoses. In: Colourick S P and Kaplan NO (eds) Methods in Enzymology 1957, Vol. III. New York: Academic Press Inc p: 88. Quoted from: Fahim FA, Esmat AY, Mady EA, Ibrahim EK. (2003): Antitumor activities of iodoacetate and dimethylsulphoxide against solid Ehrlich carcinoma growth in mice. Biol Res. 2003;36(2):25362-.

20. Gornall AG, Bardawil CJ and David MM. (): Determination of serum proteins by means of the Biuret reagent. J. Biol. Chem. 1949; 
177: 751756-. Quoted from: Pyun CW, Han KH, Hong GE and Lee CH. (2013): Effect of curcumin on the increase in hepatic or brain phosphatidylcholine hydroperoxide levels in mice after consumption of excessive alcohol. Biomed Res Int. 2013; 2013:242671.

21. Rajkowski KM, Cittanova N, Urios P and Jayle MF. An enzyme-linked immunoassay of testosterone. Steroids, 1977, 30.1: 129137-.

22. Nishikimi M, Roa NA and Yogi K. Measurement of superoxide dismutase Biochem. Biophys. Res. Common. 1972; 46:849854-. Quoted from: Madkour FF \& Abdel-Daim, MM. (2013). Hepatoprotective and Antioxidant Activity of Dunaliella salina in Paracetamolinduced Acute Toxicity in Rats. Indian journal of pharmaceutical sciences, 75(6), 642-648. PMID: 24591738.

23. Aebi H. Catalase in vitro. In: Methods in enzymology. Academic Press, 1984. p. 121126-. Quoted from: Mbarki S, Dhibi S, Bouzenna, H, et al. (2016). Effects of $\mathrm{MgCl} 2$ supplementation on blood parameters and kidney injury of rats exposed to $\mathrm{CCl}$. Open Life Sciences, 11(1), pp. 250258-.

24. Abatan SM and Olayemi M. The Role of Statistical Software in Data Analysis. International Journal of Applied Research and Studies (iJARS) ISSN, 2014, 22789480-.

25. Rahman MS, Kang KH, Arifuzzaman S, Pang WK, Ryu DY, Song WH, et al. Effect of antioxidants on BPA-induced stress on sperm function in a mouse model. Scientific reports, 2019, 9.1: 10584

26. Karimi Z, Mirza Alizadeh A, Ezzati Nazhad Dolatabadi J, and Dehghan P. Nigella sativaand its Derivatives as Food Toxicity Protectant Agents. Advanced pharmaceutical bulletin, 2019, 9.1: 22

27. Marbat MM, Mohmed Abid Ali and Hadi AM. The use of Nigella sativa as a single agent in treatment of male infertility. Tikret Journal of Pharmaceutical Sciences, 2013, 9.1: 1929-.

28. Klaunig JE, Wang $\mathrm{Z}, \mathrm{Pu} \mathrm{X}$ and Zhou $\mathrm{S}$. Oxidative stress and oxidative damage in chemical carcinogenesis. Toxicology and applied pharmacology, 2011, 254.2: 8699-

29. Kadry MS, Tarek KA and Mousa AA. Oxidative and Hormonal Disruptions Underlie Bisphenol A-Induced Testicular Toxicity in Male Rabbits. Int J Bio Food Vet Agri Engin, 2014, 8.11: 11741180-.
30. Hatef A, Zare A, Alavi SM, Habibi HR and Linhart O. Modulations in androgen and estrogen mediating genes and testicular response in male goldfish exposed to bisphenol A. Environmental toxicology and chemistry, 2012, 31.9: 20692077-

31. Kumar TR and Muralidhara. Induction of Oxidative Stress by Organic Hydroperoxides in Testis and Epididymal Sperm of Rats In Vivo. Journal of Andrology, 2007, 28: 4153341545

32. Tawfeek FK, Ahmed SM and Kakel SJ. Effect of Nigella sativa oil treatment on the sex organs and sperm charactors in rats exposed to hydrogen peroxide. Mesopotamia Journal of Agriculture, 2006, 34.1: 28-

33. Hadi MA, Zaidan HK, Natah TM and AlSaadi AH. Protective effect of plants extract mixture on sperm abnormalities, testicular and epididymal tissues in diabetic male rats. J Nat Sci Res, 2013, 3.9: 2837-

34. Al-Shdefat RI, Abd-ElAziz MA and AlSaikhan FI. Genoprotective and genotoxic effects of thymoquinone on doxorubicininduced damage in isolated human leukocytes. Tropical Journal of Pharmaceutical Research, 2014, 13.12: 20152020-

35. Wu HJ, Liu C, Duan WX, Xu SC, He MD, Chen $\mathrm{HC}$, et al. Melatonin ameliorates bisphenol A-induced DNA damage in the germ cells of adult male rats. Mutation Research/Genetic Toxicology and Environmental Mutagenesis, 2013, 752.167-57 :2-

36. Ulutas OK, Yildiz N, Durmaz E, Ahbab MA, Barlas $\mathrm{N}$ and Cok I. An in vivo assessment of the genotoxic potential of bisphenol A and 4-tert-octylphenol in rats. Archives of toxicology, 2011, 85.8: 9951001-

37. Meeker JD, Calafat AM and Hauser R. Urinary bisphenol A concentrations in relation to serum thyroid and reproductive hormone levels in men from an infertility clinic. Environmental science \& technology, 2009, 44.4: 14581463-

38. Cavalieri EL and Rogan EG. Is bisphenol A a weak carcinogen like the natural estrogens and diethylstilbestrol?. IUBMB life, 2010, 62.10: 746751 -

39. Sangai NP, Verma RJ and Trivedi MH. Testing the efficacy of quercetin in mitigating bisphenol A toxicity in liver and kidney of mice. Toxicology and industrial health, 2014, 30.7: $581597-$ 
40. Kamarzaman S, Sha'ban $M$ and Abdul Rahman S. Effects on mouse spermatogenesis and DNA fragmentation following exposure to cyclophosphamide and thymoquinone. Eur Int J Sci Technol, 2013, 2: 119136-

41. El-Beshbishy HA, Aly HAA and El-Shafey M. Lipoic acid mitigates bisphenol A-induced testicular mitochondrial toxicity in rats. Toxicology and industrial health, 2013, 29.10: 875887

42. Abdel-Wahab WM. Thymoquinone attenuates toxicity and oxidative stress induced by bisphenol A in liver of male rats. Pak $\mathbf{J}$ Biol Sci, 2014, 17.11: 115260-

43. Juma FT and Abdulrahman HMA. The effects of Nigella sativa oil administration on some physiological and histological values of reproductive aspects of rats. The Iraqi Journal of Veterinary Medicine, 2011, 35.2: 5260-

44. Cha BS, Koh SB, Park JH, Eom A, Lee1 $\mathrm{KM}$ and Choi HS. Influence of occupational exposure to bisphenol A on the sex hormones of male epoxy resin painters. Molecular \& Cellular Toxicology, 2008, 4.3: 230234-

45. Nakamura D, Yanagiba $Y$, Duan $Z$, Ito $Y$, Okamura A, Asaeda N, et al. Bisphenol A may cause testosterone reduction by adversely affecting both testis and pituitary systems similar to estradiol. Toxicology letters, 2010, 194.125-16:2-

46. Al-Seeni MN, El Rabey HA, Al-Hamed AM, and Zamazami MA. Nigella sativa oil protects against tartrazine toxicity in male rats. Toxicology reports, 2018, 5: 146155-

47. Kourouma A, Peng D, Chao Q, Yaima M, Lopez T, Liu Changjiang L, et al. Bisphenol A induced reactive oxygen species (ROS) in the liver and affect epididymal semen quality in adults Sprague-Dawley rats. Journal of Toxicology and Environmental Health Sciences, 2014, 6.4: 103112-

48. Danladi J, Ahmed SA, Akpulu SP, Owolagba GK, Iduh MU and Mairiga AA. Protective effect of cool extraction of Black Seed (Nigella Sativa) oil against CCl4-Induced oxidative damages in wistar rats testis. IOSR-J Pharm Bio Sci, 2013, 5: 6874-

49. Al-Malki AL and Sayed AAR. Thymoquinone attenuates cisplatin-induced hepatotoxicity via nuclear factor kappa- $\beta$. BMC complementary and alternative medicine, 2014, 14.1: 282

50. Mosbah R, Djerrou Z, and Mantovani A. Protective effect of Nigella sativa oil against acetamiprid induced reproductive toxicity in male rats. Drug and chemical toxicology, 2018 , 41.2: 206212-. 


\title{
الملخص العربى
}

\section{التغييرات الوراثية الخلوية والكيميائية الحيوية التي يسببها ثنائي فينول أ على خصية الفئران البيضاء والوقاية المحتملة لزيث الحبة السولية السوداء}

\author{
أسماء حسينى محمد عطوة'، أمل عبد المجيذ محمد أحمد'، نعمات فاروق حامد'، أميرة عبد الرعوف محمد' \\ 'قسم الطب الثرعي والسموم ـ كلية الطب بنات ـ جامعة الأزهر ـ القاهرة \\ بقسم بيولوجيا الخلية ـ المركز القومى للبحوث بالدقى ـ القاهرة
}

الخلفية: ثنائي فينول أهو مركب كيميائي ذو تأثير استروجيني (له القدرة علي محاكاة هرمون الاستروجين)، هو واحد من أعلى المو اد الكيميائية من حيث حجم الإنتاج في العالم والذي يستخدم في صناعة البلاستيك المسمى بولي كربونات، و الر اتينجات وطلاءِ الطبقة الداخلية التي تغلف العلبِ المستخدمِِ لحفظٍ الطعامِ و المشروبات. ثنائي فينول أ معروف أن له تأثثر ات سامة على الأنظمة المختلفة في الإنسان و الحيوان. وكان الهدف من هذه الدر اسة هو تقييم التغير ات الور اثية الخلوية

و الكيميائية الحيوية التي يسبيها بيسفينول أ على خصية الفئران البيضاء و التأثير الوقائي المحتمل لزيت الحبة السوداء. المواد والطرق: أجريت هذه الدر اسة على (•^ فأر)، مقسمة إلى أربع مجموعات (• ب فأر) لكل منهم. المجموعة الأولى: الضابطة سلبية، المجمو عة الثانية: تم إعطاؤها زيت الحبة السوداء (r مل / كجم من وزن الجسم)، المجموعة الثالثة: تم إعطاؤ ها ثنائي فينول أ (0 مغ / كجم من وزن الجسم)، المجموعة الر ابعة تم إعطاؤها ثنائي فينول أ + زيت الحبة السوداء مماثل للجر عات السابقة. تم جمع الدم والخصية و البربخ للتقييم الكيميائي و الحيوي. النتائج: تسبب ثنائي فينول أ في انخفاض كبير في عدد الحيو انات المنوية، و المحتوى الكلي للحمض النووي، الحمض النووي الريبي و البروتين في الخصية، كما تسبب في زيادة كبيرة في تلف الحمض النووي وتتو هات الر أس و الذيل في الحيو انات المنوية، مقارنة مع المجمو عة الضابطة. بينما لوحظ تحسن كبير في عدد الحيو انات المنوية، و المحتوى الكلي للحمض النووي، و الحمض النووي الريبي و البروتين مع انخفاض كبير في تلف الحمض النووي من الحيو انات المنوية وتثو هات الر أس والذيل في المجموعة التي أعطيت ثنائي فينول أ + زيت الحبة السوداء مقارنة مع المجموعة التي أعطيت ثنائي فينول أ فقط. أيضًا، أظهرت مجمو عة ثنائي فينول أ انخفاضًا كبيرًا في مستويات هرمون التستوستيرون و الكاتالاز في الدم، في حين أن هناك زيادة كبيرة في سوبر أكسيد ديسموتاز (SOD)مقارنةً بالمجموعة الضابطة. ومع ذلك، أظهرت مجمو عة زيت الحبة السوداء+ ثنائي فينول أ تحسنا ملحوظا في مستويات هرمون التستوستيرون و الكاتلاز و سوبر أكسيد ديسموتاز(SOD) في الدم، مقارنة مع مجمو عة ثنائي فينول أ. الاستتتاجات: أدى تعرض الفئر ان إلى ثنائي فينول أ إلى حدوث سمية تناسلية من خلال إحداث تلف كبير في الحمض النووي وضعف تخليق الحمض النووي، الحمض النووي الريبي والبروتين في أنسجة الخصية. يخفف زيت الحبة السوداء الضرر التأكسدي في خصية الفئر ان عن طريق تنظيم أنشطة مضادات الأكسدة الإنزيمية. 